\title{
Erratum to: Effect of Slag Chemistry on the Desulfurization Kinetics in Secondary Refining Processes
}

\author{
JIN GYU KANG, JAE HONG SHIN, YONGSUG CHUNG, and JOO HYUN PARK
}

DOI: $10.1007 / \mathrm{s} 11663-017-0980-2$

(C) The Minerals, Metals \& Materials Society and ASM International 2017

\section{Erratum to: METALLURGICAL AND MATERIALS \\ TRANSACTIONS B. DOI 10.1007/ \\ S11663-017-0948-2}

THERE is an error in the expression of 'overall mass transfer coefficient'. Therefore, the following expression should be corrected.

$$
\left(=k_{o} \cdot A V\right) \rightarrow\left(=k_{o} \cdot[A / V]\right)
$$

JIN GYU KANG, JAE HONG SHIN, and JOO HYUN PARK are with the Department of Materials Engineering, Hanyang University, Ansan 15588, Korea. Contact email: basicity@hanyang.ac.kr YONGSUG CHUNG is with the Department of Advanced Materials Engineering, Korea Polytechnic University, Siheung 429-793, Korea.

The online version of the original article can be found under doi: 10.1007/s11663-017-0948-2.

Article published online April 27, 2017. 